\title{
Author Correction: A transgenic approach for controlling Lygus in cotton
}

Anilkumar Gowda, Timothy J. Rydel, Andrew M. Wollacott, Robert S. Brown, Waseem Akbar, Thomas L. Clark, Stanislaw Flasinski, Jeffrey R. Nageotte, Andrew C. Read, Xiaohong Shi, Brent J. Werner, Michael J. Pleau \& James A. Baum

Correction to: Nature Communications https://doi.org/10.1038/ncomms12213, published online 18 July 2016

The original version of this Article contains an error in the title of Table 2, which incorrectly states Cry51Aa2.834_16 accumulation in units of ' $\mu \mathrm{g} \mathrm{mg} \mathrm{g}^{-1}$ dry weight' in place of ' $\mu \mathrm{g} \mathrm{g}^{-1}$ dry weight'. The correct version of this Table appears below as Table 1.

Published online: 26 February 2020

\begin{abstract}
(c) (i) Open Access This article is licensed under a Creative Commons Attribution 4.0 International License, which permits use, sharing, adaptation, distribution and reproduction in any medium or format, as long as you give appropriate credit to the original author(s) and the source, provide a link to the Creative Commons license, and indicate if changes were made. The images or other third party material in this article are included in the article's Creative Commons license, unless indicated otherwise in a credit line to the material. If material is not included in the article's Creative Commons license and your intended use is not permitted by statutory regulation or exceeds the permitted use, you will need to obtain permission directly from the copyright holder. To view a copy of this license, visit http://creativecommons.org/licenses/by/4.0/.
\end{abstract}

(C) The Author(s) 2020 
Table 2 . Cry51Aa2.834_16 accumulation ( $\mu \mathrm{g} \mathrm{g}^{-1} \mathrm{dry}$ weight) in various tissues of transgenic cotton plants.

\begin{tabular}{llcccc}
\multirow{2}{*}{$\begin{array}{l}\text { Sampling } \\
\text { time (DAP) }\end{array}$} & Tissue & \multicolumn{2}{l}{ Transgenic events } \\
\cline { 2 - 6 } & & GH_A710504 & GH_A772050 & GH_A714695 & GH_A767631 \\
\hline 45 & Leaf & $505.68 \pm 79.36$ a A & $519.98 \pm 46.50$ a A & $381.89 \pm 27.09$ a A & $321.02 \pm 36.75$ a A \\
70 & Square & $935.31 \pm 115.04$ ab B & $1164.21 \pm 98.09$ b A & $854.43 \pm 79.40$ a A & $752.53 \pm 91.76$ a A \\
& Leaf & $424.68 \pm 51.12$ a A & $398.21 \pm 58.56$ a A & $379.86 \pm 33.10$ a A & $292.69 \pm 15.07$ a A \\
& Square & $1070.63 \pm 85.83$ b B & $714.49 \pm 179.65$ a A & $859.93 \pm 167.21$ ab A & $641.59 \pm 52.43$ a A \\
90 & Boll & $450.41 \pm 26.25$ a A & $546.03 \pm 77.72$ a A & $392.48 \pm 55.36$ a A & $459.96 \pm 54.52$ a A \\
& Leaf & $396.97 \pm 43.72$ ab A & $472.07 \pm 35.73$ b A & $365.14 \pm 28.39$ ab A & $246.04 \pm 15.53$ a A \\
& Square & $703.45 \pm 139.79$ ab A & $1038.1 \pm 122.07$ c A & $804.14 \pm 119.61$ bc A & $506.74 \pm 74.59$ a A \\
& Boll & $498.99 \pm 65.54$ ab A & $706.36 \pm 104.87$ b A & $416.24 \pm 80.77$ a A & $497.78 \pm 110.28$ ab A
\end{tabular}

DAP days after planting.

Means followed by different lower case letters within a row and different uppercase letters within a column are significantly different from each other at $P \leq 0.05$ (LSMEANS test, $n=8$ ). Data shown as mean \pm s.e.m. 